\title{
California-Alaska Trade, 1851-1867: The American Russian Commercial Company and the Russian America Company and the Sale/Purchase of Alaska
}

\section{Norman Saul}

Early relations between democratic United States and autocratic Russian Empire were surprisingly good, thanks to mutually beneficial commercial connections and Anglophobia. U.S.-Baltic trade rose rapidly from 1763 to 1812 with New England shippers gaining handsome profits from delivering sugar, coffee, and other "colonial goods" to Russian Baltic ports, mainly St. Petersburg, and returning with "naval stores"- - hemp, sailcloth, and iron. By 1800 RussianAmerican commerce began in another quarter, the Pacific coast. The same motive that brought Russian promyshlenniki to Alaska - the quest for furs, mainly sea otter for the China market-attracted Yankee entrepreneurs, such as Joseph O'Cain. "Bostonians" provided the ships and navigational talent to haul the skins to China and delivered supplies to Alaska, while the Russians mobilized and managed native labor. ${ }^{1}$

1 Background studies for early Russian-American relations that cover this topic are by Nikolai Bolkhovitinov, The Beginnings of Russian-American Relations, 1775-1815 (Harvard, 1975), Alfred Crosby, Jr., America, Russia, Hemp, and Napoleon: American Trade with Russia and the Baltic, 1783-1812 (Ohio State, 1965), and Norman Saul, Distant Friends: The United States \& Russia, 1763-1867 (Kansas, 1991). Foundation works dealing more specifically with Russian Alaska include: Bolkhovitinov, Russko-Amerikanskie otnosneniia i prodazha Alaski (Nauka, 1990); Frank Golder, Russian Expansion on the Pacific, 1641-1850: An Account of the Earliest and Later Expeditions to the Arctic Regions... (Clark, 1914); P. A. Tikhmenev, A History of the Russian-American Company, trans, and eds, Richard Pierce and Alton Donnelly (University of Washington Press, 1978); Richard Pierce, The Russian Governors: Builders of Alaska, 1818-1867 (Limestone, 1986); Svetlana Fedorova, The Russian Population in Alaska and Califronia, Late $18^{\text {th }}$ Century-1867 (Limestone 1973); and Lydia Black, Russians in Alaska, 1732-1867 (University of Alaska Press, 2004). For a more recent general survey, see Ilya Vinkovetsky, Russian America: An Overseas Colony of a Continental Empire, 1804-1867 (Oxford, 2011).

Richard Pierce, through his own Limestone Press, has also produced a number of important translations of documents, as well as has Basil Dmytryshyn with the Oregon Historical Society. The capstone of these publications on Russian Alaska is clearly Bolkhovitinov's three volume history that remains only in Russian: Istoriia russkoi Ameriki, 1732-1867 (Moscow: Mezhdunar. Otnosheniia, 1997-99) 
At that time commercial cooperation in the Pacific was transitory between the two countries. Russia soon acquired its own ships and set out on voyages of discovery, and Great Britain also became more active in the area, while the United States concentrated more on its direct trade with China and on whaling. In 1806 Nikolai Rezanov established direct contact with the Spanish in California and a supply base was established at Fort Ross in 1812, but this proved inconvenient for either food or hunting expeditions, and encountered opposition from natives, Spain, and the United States. Fort Ross was sold in 1841 to an American, John Sutter.

Since 1799 the Russian America Company (RAC) held monopoly rights by imperial charter to administer and exploit the vaguely defined Russian territory in northwest America. Sea otter, beaver, and fox furs were gathered from native villages or by company hunting parties along the coast, stored in warehouses at Kodiak or Sitka, then shipped to China by way of Siberia or through the port of Canton. Sales financed the purchase of tea for the Russian market sent overland or by sea to St. Petersburg. But by the 1840 s this profitable operation faced challenges from depletion of animal resources, competition from the British Hudson's Bay Company, and by the American settlement of the Oregon territory. The RAC income fell from 425,628 silver rubles in 1845 to 212,648 in 1849. In no year after 1848 did annual receipts reach 300,000 rubles, and the average for the $1850 \mathrm{~s}$ declined to $150,000 .^{2}$ Nonetheless, the charter of RAC to operate its monopoly in Northwest America was renewed in 1842 for the usual twenty years. There was no alternative.

Hard times, however, brought new life to the management of RAC. Rear Admiral Adolf Etholin, who served as "governor" from 1840 to 1845 , was a spokesman for innovation. In 1848 a mineral prospector, Peter Doroshin, was sent to investigate mining possibilities in Alaska, especially coal for steamships. ${ }^{3}$ RAC also invested in a profitable business of their waters - whaling. The Russians had proposed joint operations with New England whalers as early as 1820, but the Yankees preferred to be independent. In 1850 RAC established the Russian Finnish Whaling Company with its center at Abo (Turku), but the first whaling ship, the Suomi, reached Alaskan water only in 1852 and the company never achieved a profitable level. ${ }^{4}$

Until mid-century the RAC was hampered by its isolation and consequent sporadic and unpredictable communications, even with its California colony, much of it due to inadequate shipping. The decline of fur resources also contributed to the depression. Nevertheless, several historians linked developments in California

2 One silver ruble was about $\$ .75$. The figures are from the published annual reports of the RAC consulted in the Russian National Library (Saltykov-Shchedrin) in St. Petersburg and microfilms of RAC records in the Library of Congress.

3 Frank Golder, "Mining in Alaska before 1867," in Alaska and Its History, edited by Morgan Sherwood (Seattle: University of Washington Press, 1967), 150-51.

4 "Ob uchrezhdenii russkago kitolovstva," Kommercheskaia Gazeta January 12, $1852,18$. 
to the Russian sale of Alaska. This examination of California-Alaska trade after 1850 will also shed further light on the reasons for the sale-purchase of $1867 .{ }^{5}$

The focus of the United States had shifted westward in the 1840s during the Mexican War and the considerable expansion of territory. ${ }^{6}$ San Francisco quickly became the major center for this activity, especially after the discovery of gold in 1848, not far from the city, producing a gold rush and attendant demand for commercial houses, banks, and utilities. Even the RAC sold supplies and participated in early mining. The boom town of San Francisco rose quickly in population, with many individuals seeking business opportunities.

In 1850 Grigory Ivanov and Martin Klinkovstrem visited California to collect the final payment for Fort Ross and to investigate future prospects for sale of Russian products. Their reports prompted the directors in St. Petersburg to send samples of goods to sell and appoint Peter Kostromitinov as the company's agent in San Francisco. Arriving at Sitka in May of that year, he conferred with chief administrator Nicholai Rozenberg before departing for California to take up his assignment. ${ }^{7}$

Rozenberg's instructions advised exploration of sales of lumber and fish, and, in the future, coal but warned that "the continuation of disorder and the absence of civil responsibility" in California may pose a danger to the property of the company." He also asked for information regarding method of sale - through commission merchants or by public auction. The RAC had been surprisingly quick to realize an advantage in new possibilities for trade with California. By 1851, San Francisco was a bustling city with a population of over 50,000. One of the commodities in demand there and on coastal steamers was ice. Since the mild climate could not furnish a natural supply, the first amounts were brought around

5 The best work on the later years of RAC is by Bolkhovitintov, Russko-amerikanskie otnosheniia i prodazha Aliaski (Nauka, 1990), but he does not examine business relations in detail.

After somewhat of a hiatus, various scholars have produced new research on Russians in Alaska, emphasizing biographies and translated documents: Natalia Shelikhova, Russian Oligarch of Alaska Commerce, edited and translated by Dawn Black and Alexander Petrov (a student-disciple of Bolkhovitinov), University of Alaska Press, 2010; Kenneth Owens, with Alexander Petrov, Empire Maker: Aleksandr Baranov and Russian Colonial Expansion into Alaska and Northern California (University of Washington Press, 2015); and Susana Rabow-Edling, Married to the Empire: Three Governors' Wives in Russian America, 1829-1864 (University of Alaska Press, 2015).

${ }^{6}$ An example is my great grandfather, John Neff, who left his studies at Otterbein College and home in Southern Ohio to go by boat as far as Omaha and then overland, driving cattle, to participate in the gold rush. He and his brother had modest success, returning by Panama steamer and up the Mississippi to buy farmland in Indiana-where I was born. John Neff (1834-1930), unpublished diary, 1854, typed copy in my possession.

7 Rozenberg to Directors, May 24/June 5 and July 23/August 4, 1851, Vol. 32, 289, 440-41, Communications Sent, Records of the Russian America Company, Record Group 261, National Archives and Record Service (microcopy 11) [hereafter cited as CS, RRAC. RG 261, NA]. Kostromitinov was also appointed the first Russian consul in San Francisco. 
South America from Boston, and the price was naturally high - but you would not want to order a mint julep on a hot Pacific steamship without it. ${ }^{8}$

Ironically, the first attempt to bring Alaskan ice to California originated in neither California nor Alaska but in Oregon. In September 1851, the American schooner Exact, owned by Crosby \& Smith of Portland, arrived at Sitka "to obtain a cargo of ice for sale in California." Having misjudged availability of ice at that time of year, the Americans inspected the lakes around New Archangel, conferred with Rozenberg on terms of a contract, and promised to return in the winter. The Russian administrator seized upon this new idea and instructed Kostromitinov "to seek out men of credit" in San Francisco for ice purchases. ${ }^{9}$

The Flavius arrived Sitka as promised in February 1852, but the Americans considered the Russian price - $\$ 75$ a ton - too high, and the ship returned empty. Two weeks later, the Bacchus, chartered by the Pacific Ice Company, a voyage inspired by Kostromitinov, appeared, and the partners on board agreed to the price on condition that credit be extended. One man remained as "security" until the ship returned with full payment. ${ }^{10}$ Thus, the first cargo of Russian ice arrived in San Francisco on April 11, 1852. A local newspaper considered this new venture in ice "a fair commencement for the enterprising gentlemen who have started this.... We congratulate our citizens on the present abundance of this luxury in San Francisco." "11 Unfortunately for the Pacific Ice Company, two ships reached San Francisco from Boston with ice the same month, and the company failed to collect enough to pay its obligation to RAC. When a second ship was sent during the summer, Rozenberg refused to sell any more on credit. ${ }^{12}$

Despite this initial failure, a group of San Francisco merchants and bankers under the leadership of Beverley C. Sanders, originally from Baltimore, formed a new company, the Russian and North American Ice Company, and negotiated with Kostromitinov for a three-year contract beginning October 21, 1852. Sanders had the advantage of being appointed that year as Collector of the Port of San Franscisco. The American company agreed to buy 1,200 tons of ice a year at $\$ 35$ a ton and furnish materials and supervisors for the construction of ice storage houses at New Archangel. The new company was incorporated before the end of the year as the American Russian Commercial Company (ARCC). ${ }^{13}$

8 Rozenberg reported in 1851 that the price of ice in San Francisco ranged from 25 to 40 cents a pound, but in Panama and Acapulco, it sold for 50-55 cents, often as high as a dollar. Rozenberg to Directors, September 10/22, ibid., 505.

9 Rozenberg to Kostromitinov, September 10/22, 1851, ibid., 497. Most likely the idea was conceived by Nathaniel Crosby, Jr., a pioneer in Pacific trade. Rosenberg to Crosby $\&$ Smith, September 10/22, 1851, ibid, 500.

${ }^{10}$ Rozenberg to Kostromitinov, March 6/18, 1852, and Rozenberg to Directors, March 7/19, ibid. 33, 37-40.

${ }^{11}$ Daily Alta California, April 12, 1852.

${ }_{12}$ Rozenberg to J. F. Hutton, July 13/25 and Rozenberg to Directors, July 13/26, vol. 33, CS, RRAC, RG 261, NA, 341. Only $\$ 8,732$ was paid on a debt of $\$ 18,750$.

${ }^{13}$ The chief stockholders (over 100 shares) of ARCC were as follows, in alphabetical order: Charles Baum 190, Charles Brenham 203, Henry Dexter 174, Henry Edwards 240, Abel Guy 390, Lucien Hermann 251, Samuel Hensley 200, Archibald Peachy 200, Samuel 
As planned, the American ships reached Alaska on November 15, 1852, and January 15,1853 , to load ice directly from the lake. Engineers and materials arrived on the Consort on December 22 to begin the largest construction project of Russian America until then. The RAC bark Ella Frances brought an additional 403 tons in May. Besides ice, salt fish packed in barrels and small quantities of lumber were also included..$^{14}$ None of the latter were successful because of dislike of Russian-style salted fish and the ready availability of lumber in California. But officials of the RAC were pleased, however, not only by additional income at low cost (native workers were paid one paper ruble per day during the short cutting season), but also by the opportunity to buy supplies from California. Moreover, a regular trade with San Francisco would provide the Russian colony with much better communications with the RAC Directory in St. Petersburg. While ice cutting and storage changed the pace of life, the territory was drawn more into the American economic orbit. ${ }^{15}$

There were also signs of troubles. Rozenberg's replacement, Alexander Rudakov, complained to Sanders that his company was not keeping on schedule and not providing satisfactory equipment. ${ }^{16} \mathrm{He}$ also objected to Kostromitinov's consent in June to the American demand that the cost of ice be reduced in order to force Boston ice out of the San Francisco market. ${ }^{17}$ Rudakov advised the directors to retain a free hand in the Pacific market and that machinery be purchased to expand fish and lumber exports. ${ }^{18} \mathrm{He}$ also resented Kostromitinov's influence, fearing company policy was determined more in San Francisco than in Alaska or St. Petersburg, and warned the directors against closer relations with Americans.

In San Francisco expansion of trade with Alaska seemed promising. Sanders, having lost his post as Collector of the Port in June 1853 due to the national Democratic victory in 1852, decided to devote all his energy to the new business and go to St. Petersburg to negotiate directly with the RAC directors. He hoped to achieve a long-term contract that would give his company exclusive rights to

Moss, Jr. 190, and Beverley Sanders 203. This represented a "who's who" of leading businessmen in the San Francisco area. Samuel Moss, Jr., an Oakland pioneer and builder, would succeed Sanders as director of ARCC. "List of Stockholders, ARCC, San Francisco, July 25, 1855," Sanders Papers.

The "Sanders Papers" were loaned to me in Providence by a descendant of Beverley Sanders. Though I urged that they be made available at a reliable public facility, such as the Brown University Library or the Rhode Island Historical Society, I have not been able to trace them recently and fear they may have been lost. Also, see my "Beverley C. Sanders and the Expansion of American Trade with Russia, 1853-1855," Maryland Historical Magazine 67, 2 (Summer 1972): 156-70.

${ }^{14}$ San Francisco Port Records, 1853, RG 36 (Bureau of Customs), NA.

${ }^{15}$ Father Ivan Veniaminov, legendary head of the Orthodox mission in Alaska, reported in 1854 that ice had become the principal business of the colony. "Torgovlia l'dom v novo-arkhangel'ske," Posrednik: gazeta promyshlenosti, khoziaistva i real'nykh nauk, October 20, 1854, 167.

${ }^{16}$ Rudakov to Sanders, July 10/22, 1853, CS 34, 172, RRAC, RG 261, NA.

${ }^{17}$ The change was to scale the purchase to $\$ 25$ a ton for the first 1,200 tons, $\$ 20$ for the next 800 tons, and $\$ 15$ for any additional tons.

${ }^{18}$ Rudakov to Directors, July 14/26, ibid., 179-81. 
market Alaska produce in the whole Pacific arena. In Washington he met with President Franklin Pierce, Secretary of State William Marcy, and Russian minister Alexander Bodisko, receiving their support and a courier's passport. Upon arrival in St. Petersburg, he began negotiations at the headquarters of the RAC. ${ }^{19}$ The timing was fortuitous, since the beginning of the Crimean War created concern about the safety of the Russian possessions in America. Although RAC negotiated separately a neutrality agreement with the British Hudson's Bay Company, commerce with Alaska was considered under British blockade. ${ }^{20}$ RAC could negotiate with Sanders with the knowledge that the territory was safe but that commerce for the duration of the war was dependent on neutral ships willing to risk running a blockade that never would be enforced. It could thus approve a long term monopoly contract with the ARCC in return for its agreement to supply the colony during the war.

While this was being worked out, Sanders discussed commercial affairs in general with Foreign Minister Karl Nesselrode, Grand Duke Constantine, and Nicholas I himself, and visited Moscow with the idea of a possible railroad project. ${ }^{21}$ On June 13/25 the RAC directors signed what Sanders termed a "treaty" for 20 years, approved by the tsar. The directors were relieved that this seemed to insure the renewal of its own charter, which would expire in 1862. In a profit sharing arrangement, RAC would do the producing and ARCC would distribute and sell. Income was to be divided equally between the two companies after expenses were deducted. These would be determined by agents of the two companies in California and Alaska. ${ }^{22}$

Sanders also agreed to other capital arrangements for RAC: upon return to the United States he ordered a 450 ton steamship in New York for $\$ 54,000$ for the company, purchased the Cyane (250 tons) for RAC, and chartered the Levanter (840 tons) to carry a cargo of general supplies to Petropavlovsk for the Russian government. Sailing under the American flag the Cyane brought essential supplies to Alaska during the war, and then was renamed Nakhimov after the war. But during Sanders absence commerce had faced difficulties: the first ice house was still unfinished, and little ice could be shipped, though lumber, produced by a new saw mill took cargo space on the Ella Frances and the RAC ship Kodiak delivered 600 barrels of salt fish, but the price was so low that Kostromitinov sent the ship on to Honolulu, where only 200 barrels were sold. The Crimean War curtailed most of sending cargoes on company ships. ${ }^{23}$

${ }^{19}$ Sanders, "A Journal of the Trip," Letterbook 1, Sanders Papers, private collection (copies in author's possession. This collection was loaned by a great granddaughter of Sanders to the author, who made copies.

${ }^{20}$ Directors to Voevodsky, April 16/28, 1854, CR 21, 109-10, and Addington to Hudson's Bay Company, March 22, 1854, copy in above, 61 .

${ }^{21}$ Sanders diary, 1854, Sanders Papers.

${ }^{22}$ Sanders to Directors, June 4/16, 1854, Letterbook, and copy of treaty, ibid. and Directors to Voevodsky, June8/20, 1854, CR 21, 109-10, RRAC, RG 261, NA. Bolkhovitinov found the original of the treaty in TsGIA, f. 18, op. 5, d. 1344, 16-20. Russko-amerikanskie otnosheniia i prodazha Aliaski, 1834-1867, 78 n19.

${ }^{23}$ Vladimir Voevodsky to Directors, May 1/13, 1854, CS 35, 30-32, RRAC,RG 261, NA. Voevodsky had just replaced Rudakov as manager of affairs in Alaska. 
Another problem was competition from Hudson's Bay Company territory by the North West Ice Company, also based in San Francisco. Upon return to California, Sanders solved the problem at a cost by agreeing to sell at least 3,000 tons of ice a year to that company to preserve the monopoly of ARCC Russian sales in California, ${ }^{24} \mathrm{ARCC}$ thus becoming mainly a wholesale operation. Meanwhile, Voevodsky pushed for expansion of ice production from a new source on Wood Island near Kodiak and planned to purchase additional ships for this route. ${ }^{25}$ RAC certainly did not help its balance sheet during the Crimean War by lavish expenditures in San Francisco. ${ }^{26}$ Sanders also purchased a modern 800 ton bark, the Zenobia, that became the major hauler of ice to California in the later 1850s, making over 15 voyages, until it was wrecked in San Francisco Bay in April 1858. ${ }^{27}$ It was replaced in 1860 by an expensive RAC purchase, a classic "Yankee clipper", Coeur de Lion, renamed Tsaritsa. Built in Portsmouth, New Hampshire, it could carry over 1,000 tons on each voyage.

Unfortunately, the man mainly responsible for obtaining ships, supplies, and markets for RAC was a victim of financial failure. On November 5, 1855, the Sanders bank failed. A local newspaper reported, "the firm has been largely engaged in Russian trade, but the failure is attributed to other causes." 28 Despite this disclaimer, an unpublicized aspect of the Russian trade probably contributed to it. A request by Voevodsky for a shipment of gunpowder had been refused by ARCC officers in Sanders absence, but he overruled them upon return, and the first shipment of 1,250 lbs arrived in Alaska in September 1855, which could be considered contraband, though RAC claimed it was for hunting. Moreover, mindful of the fragile state of San Francisco business, stockholders were not pleased with the extended nature of Sanders operations that included ventures in coal mining on the Kenai Peninsula in $1956 .{ }^{29}$

${ }^{24}$ This matter was complicated by the lease by RAC to the Hudson's Bay Company of the mouth of the Stikhin River that was claimed by RAC. This provided exit to the Pacific for HBC. The Ida brought 300 tons of ice from there in the summer of 1854 . Voevodsky to Directors, June 8/20, ibid, 85; San Francisco Port Records, vol 7, RG 36, NA.

${ }^{25}$ Voevodsky to Sanders, January 24/February 5, 1855, and Voevodsky to Furuhelm, May 27/June 8, 1855, CS 36, 15,65, RRAC, RG 261, NA. This transaction is summarized in Kommercheskaia Gazeta, December 26, 1856, 602-03.

${ }^{26}$ By early 1855, it had ordered 740 gallons of wine, 3,000 flasks of rum, cognac, brandy and whisky, 1,800 lbs. of coffee, 50,000 Manila cigars, and 5,400 lbs. of tea, along with quantities of clothing, shoes, flour, sugar, and salt. In fact, costs greatly exceeded the income in 1855 because of additional purchases of new equipment for coal mining and ice cutting, and high shipping charges because of war. Much of his was paid by remittances from St. Petersburg through the Sanders and Brenham Bank in San Francisco. Compiled from Voevodsky's correspondence to directors, and to Sanders, and San Francisco Port records.

${ }^{27}$ Voevodsky to Directors, June 6/18, ibid., 83.

28 "Continuation of the Annals of San Francisco," comp. Dorothy Huggins, California Historical Society Quarterly 16 (1937), 338. Sanders returned to Baltimore in 1857, regained business stature and later found employment in the New York port customs office and died in Newark, New Jersey, in 1883. Sanders Papers.

${ }^{29}$ Overlapping business involvements also produced opposition to Sanders. Charles Baum, secretary of ARCC was also vice president of the Bellingham Bay (Washington) 
Efforts by Sanders to obtain relief from RAC fell on deaf ears. No wonder, considering the results of the first year of the "Sanders Treaty." ${ }^{30}$ Although the cost of production ( $\$ 3.25$ a ton) and export duty ( $\$ .75$ a ton) were paid upon delivery, RAC received little more than to offset its other expenditures. From the beginning ARCC took advantage of keeping the accounts. Voevodsky claimed that the Americans padded their expenses to recoup more. He calculated that the treaty should have yielded over $\$ 65,000$ for the 3,385 tons of ice shipped. Instead, the Russian share was only a little more than $\$ 2,000 .{ }^{31}$ ARCC, under direction of J. Mora Moss a wealthy banker in Oakland, continued to concentrate on ice and was successful especially in 1857 and 1858 with imports of over 4,000 tons in those years, though RAC continued to complain of ARCC's manipulation of accounts.

Coal prospects appeared better and RAC made a considerable investment in buildings and equipment on the Kenai Peninsula. Initial samples were positive, but the first - and only-shipment of Alaskan coal came to San Francisco in August 1956. To Voevodsky's surprise reports were that it was too inferior for the market. ${ }^{32}$ The only coal sold by the company in California was 150 tons of British New Castle coal brought to Alaska by the Tsaritsa in $1860 .^{33}$

Two other problems plagued Alaska-California trade. An unusually mild winter in 1855-56 reduced the amount of ice available for cutting and shipping to San Francisco, leading to both companies to look for suitable sites for ice farther north. A source would be found at Wood Island, near Kodiak. The first ice from there would shipped in $1858 .{ }^{34}$ The other problem was that large vessels loaded with ice were vulnerable to rocks below the surface, especially prevalent in Sitka harbor. This was the case with the workhorse of the ARCC, the loss of the Zenobia, in 1858, the Kodiak of RAC in 1860, and the pride of the RAC that replaced it, the New England built Yankee clipper Tsaritsa in 1861. This also bolstered the shift to waters that were less susceptible to such accidents.

Nevertheless, Hampas (Ivan) Furuhelm, the new "governor," managed to negotiate a contract, that replaced the "Sanders Treaty" in 1860. It provided for

\footnotetext{
Coal Company, which naturally saw a threat.

${ }^{30}$ Sanders returned to Baltimore, recovered his stature somewhat, then was employed in the Customs Collectors Agency in New York for a number of years before his death in 1883. Sanders Papers.

${ }^{31}$ Voevodsky to Directors, February 7/19, 1856, CS 57, 19-22, RG 261, NA. He listed expenditures as follows: RAC-first ice house in New Archangel \$7,000, second \$10,000, third on Wood Island $\$ 12,000$, instruments and horses $\$ 4,080$, total $\$ 33,080$; ARCCZenobia $\$ 15,000$, ice house in San Francisco $\$ 12,161$, one in Sacramento $\$ 8,075$, total $\$ 25,236$. But he claimed the ship should not be counted.

${ }^{32}$ Voevodsky to Directors, October 24/November 5, 1856, and Voevodsky to Kostromitinov, December 24/January 5, 1856, CS 37, 182-83, 231. One factor preventing coal from Alaska may have been the interlocking nature of American business. Charles Baum, a major investor in ARCC, was also vice president of the Bellingham Bay Coal Company (Washington). The San Francisco Directory for the Year 1860 (San Francisco, 1860), 455.

${ }^{33}$ Ivan Furuhelm to Kostromitinov Jan. 28//Feb. 9, 1960, CS 42, 7, RG 261.

${ }^{34}$ See Appendix I.
} 
a simpler arrangement: ARCC agreed to pay a flat rate of $\$ 7$ a ton and $\$ 8$ a ton for shipment on RAC ships, and guaranteeing purchase of 3,000 tons a year. ${ }^{35}$ Ice became the major business between California and Alaska with yearly average of 4,000 tons shipped, thanks to the Tsaritsa that made three trips in 1860 , before its wreck in early 1861 . Subsequent shipments on chartered ships achieved a record total in 1864 with 4,785 tons. ${ }^{36}$ Income would have exceeded $\$ 60,000$ from ice for these years, much greater than the income from furs. ${ }^{37}$

Considerable capital expenditures were involved, however, in the purchase of ships and construction of new ice houses on Wood Island, which had a convenient fresh water pond. Ice storage required thick walls and deep foundations; the first of three on Wood Island was 102 feet long, 46 feet wide, and 25 feet high. ${ }^{38}$

Unfortunately, RAC was plagued by bad luck concerning ships. Poor Russian seamanship may have contributed to this. In 1860 the Kodiak was lost in a storm and the following year the Tsaritsa, loaded with ice, was badly damaged in being towed out of New Archangel onto rocks, witnessed by an inspector of the Ministry of Navy, Captain Pavel Golovin. ${ }^{39}$ The wreck of the Tsaritsa was perhaps the last straw, proving that the RAC could not compete in business with its American partner. When its twenty-year charter expired the next year, it was renewed for only one year, clear evidence that Russia was ready to sell, strongly favored by the naval and finance ministries, in order to concentrate on the Far East and Vladivostok. But the only potential buyer was engaged in a major civil war, so a sale had to wait until after its conclusion. ${ }^{40}$

The Alaska-California ice business continued from the facilities on Wood Island, but the American company was unwilling to supply the year around supervisors. ${ }^{41}$ Besides, new competition from the recently completed transcontinental railroad that supplied ice by the carload in regular and predictable shipments from mountain lakes to the West Coast, before electric or gas refrigeration entered the picture by $1880 \mathrm{~s}$. But artificial production of ice was

${ }^{35}$ Capt-Lt. P. N. Golovin, Obzor Russkikh kolonii v Severnoi Amerike, supplement to Morskoi Sbornik 57, 1 (1862), 188.

${ }^{36}$ Appendix I, is a list of over 100 voyages, $1851-67$ with dates and cargoes, obtained from San Francisco Port Records, RAC records, and San Francisco newspapers, and Appendix II, a summary of ships in the ice trade.

${ }^{37}$ Costs are difficult to calculate. Native labor was cheap, but regular supervisors had to be imported on a contract basis, which would be expensive and probably reduced net income by half.

${ }^{38}$ Voevodsky to Kostromitinov, January 19/31, 1857, CS 38, 1, RAC, RG 261, NA.

39 Golovin to parents, March 31/April 12,1861, "Iz putevykh pisem P. N. Golovina," edited by Vladimir Rimsky-Korsakov, Morskoi Sbornik 58, 6 (1863), 306. Golovin died soon after his return to Russia. The letters describing his journey from St. Petersburg to New Archangel via London, New York, Washington, and San Francisco, and back, were edited by a close friend, the brother of the composer.

${ }^{40}$ Some opposition occurred in Russia from stockholders of the company, which included Alexander II, and from xenophobic Russians who resented any loss of territory.

${ }^{41}$ Information is scarce since commerce between Alaska and California after the purchase was domestic instead of foreign and thus was no longer recorded at the Customs house in San Francisco. 
still expensive and only feasible on a large scale - until much later when home refrigerators became common. Besides, many consumers preferred "natural" ice from frozen lakes. The icebox would remain a fixture in American homes for many more years. ${ }^{42}$

The results of the California-Alaska trade was the major factor in the Russian decision to sell Alaska to the United States. That decision was reached by 1862 after the reports of the inspectors sent to Alaska by the Ministry of Finance and the Ministry of Navy. But the actual sale had to wait until Union victory in the American civil war. It was apparent by that time that the Russian America Company had failed to establish a profitable relationship with its California neighbor. Ice was clearly the only product it could sell there. Coal, fish, and lumber proved unmarketable. Especially apparent was the mismanagement of the RAC in the shipping of ice with the costly loss of expensive vessels. Another factor was the shift of the source from Sitka to Kodiak, which denied one of the benefits-the advantage of a return of supplies from California to the Russian administrative center at Sitka. Certainly the administrative staff of Russian America could not have been pleased with the shift of the ice trade to the Kodiak area, nor probably the income of the Tlingit natives to the Aleuts to the north.

${ }^{42}$ The author remembers the iceman making regular deliveries to his family's farm late in the 1930s, before electricity reached it. 
Appendix $\mathrm{I}^{43}$

EXPORTS FROM ALASKA TO SAN FRANCISCO, 1851-1867

\begin{tabular}{|c|c|c|c|c|c|}
\hline \multicolumn{2}{|c|}{ Departure Date } & Ship & Cargo & Owner & Arrival \\
\hline \multirow[t]{2}{*}{1851} & January & Prince Menshikov & Equipment & RAC & January \\
\hline & September & Exact & None & Crosby & September \\
\hline \multirow[t]{4}{*}{1852} & January & Prince Menshikov & Fish-150 barrels & RAC & February \\
\hline & February & Flavius & None & Crosby & March 17 \\
\hline & March & Bacchus & Ice -250 tons & Pacific Co. & April 11 \\
\hline & July & Whiton & None & Hudson Bay & Nov. 27 \\
\hline \multirow[t]{6}{*}{1853} & February & Kodiak & Fish-150 barrels & RAC & Feb. 23 \\
\hline & February & Consort & Ice-220 tons & ARCC & March 5 \\
\hline & April & Ella Frances & Ice -403 tons & ARCC & May 10 \\
\hline & July & Ella Frances & Ice -30 tons & ARCC & Aug. 8 \\
\hline & September & Shelikhov & Lumber & RAC & Oct. 22 \\
\hline & November & Ella Francis & Ice -480 tons & ARCC & Dec. 14 \\
\hline \multirow[t]{6}{*}{1854} & January & Kodiak & Fish-600 barrels & RAC & Feb. 9 \\
\hline & January & Harriet Thompson & Ice -240 tons & Northwest & Feb. 14 \\
\hline & February & Ella Francis & Ice-435 tons & ARCC & Feb. 18 \\
\hline & March & Zenobia & Ice- 880 tons & ARCC & April 10 \\
\hline & June & Zenobia & Ice -880 tons & $\mathrm{ARCC}$ & July 5 \\
\hline & September & Zenobia & Ice -425 tons, fish & ARCC & Oct. 14 \\
\hline \multirow[t]{6}{*}{1855} & February & Zenobia & Ice-770 tons & ARCC & Feb. 21 \\
\hline & March & Chalcedon & Ice-265 tons & Charter & March 29 \\
\hline & June & $\begin{array}{l}\text { Zenobia } \\
\quad \text { (from Kodiak) }\end{array}$ & Ice -580 tons & $\mathrm{ARCC}$ & Aug. 9 \\
\hline & September & Polynesia & Ice- $-1,200$ tons & Charter & Sept. 20 \\
\hline & October & Zenobia & Ice- -570 tons, fish & ARCC & Oct. 30 \\
\hline & November & Cyane & Lumber-26,891 ft. & ARCC & Dec. 14 \\
\hline \multirow[t]{5}{*}{1856} & February & Zenobia & Ice- -710 tons & ARCC & March 15 \\
\hline & May & Zenobia & Ice-none & ARCC & June 7 \\
\hline & July & Zenobia & Lumber & $\mathrm{ARCC}$ & August 11 \\
\hline & August & Lucas (from Kenai) & Coal-500 tons & RAC & September \\
\hline & November & Nakhimov (Cyane) & Furs & RAC & Nov. 24 \\
\hline \multirow[t]{6}{*}{1857} & January & Zenobia & Ice -830 tons & ARCC & Jan. 30 \\
\hline & January & Kodiak & Ice-300 tons & RAC & Feb. 17 \\
\hline & March & Zenobia & Ice- 870 tons & ARCC & April 4 \\
\hline & March & Nakhimov & ce -260 tons & RAC & April 18 \\
\hline & June & Zenobia & Ice -810 tons & ARCC & August 1 \\
\hline & August & Nakhimov & Ice-275 tons & RAC & Sept. 9 \\
\hline
\end{tabular}

${ }^{43}$ Statistics compiled from Records of the Russian America Company (RG 261), San Francisco Port Records (RG 36), and San Francisco newspapers. 


\begin{tabular}{|c|c|c|c|c|c|}
\hline \multicolumn{2}{|c|}{ Departure Date } & Ship & Cargo & Owner & $\begin{array}{l}\text { Arrival } \\
\text { Date }\end{array}$ \\
\hline & October & Zenobia & Ice-900 tons & $\mathrm{ARCC}$ & Oct. 18 \\
\hline & October & Kodiak & Ice-300 tons & RAC & Nov. 20 \\
\hline \multirow[t]{7}{*}{1858} & March & Nakhimov & Ice-240 tons, furs & RAC & March 21 \\
\hline & April & Zenobia & Ice- 835 tons & $\mathrm{ARCC}$ & Wrecked \\
\hline & May & $\begin{array}{l}\text { Kodiak } \\
\quad \text { (from Kodiak) }\end{array}$ & Ice-275 tons & $\mathrm{RAC}$ & June 6 \\
\hline & June & Vitula & Ice-1,200 tons & Charter & June 17 \\
\hline & June & Phenix & Whale oil & Charter & July 6 \\
\hline & August & $\begin{array}{l}\text { Kodiak } \\
\quad \text { (from Kodiak) }\end{array}$ & Ice-275 tons & $\mathrm{RAC}$ & Oct. 8 \\
\hline & September & $\begin{array}{l}\text { Cartyne } \\
\quad \text { (from Kodiak) }\end{array}$ & Ice $-1,000$ tons & Charter & Sept. 26 \\
\hline \multirow[t]{8}{*}{1859} & January & Kodiak & Furs, fish, lumber & $\mathrm{RAC}$ & Feb. 10 \\
\hline & February & Nakhimov & Ice-255 tons & RAC & March 1 \\
\hline & April & Kodiak (Kodiak) & Ice-250 tons & $\mathrm{RAC}$ & April 30 \\
\hline & June & Sophia Adelaide & Ice-545 tons & Charter & June 17 \\
\hline & July & Aspasia (Kodiak) & Ice-700 tons & Charter & Aug. 9 \\
\hline & July & Kodiak (Kodiak) & Ice-250 tons & $\mathrm{RAC}$ & Aug. 21 \\
\hline & September & Sophia Adelaide & Ice-560 tons & Charter & Sept. 26 \\
\hline & October & $\begin{array}{l}\text { Gray Feather } \\
\text { (Kodiak) }\end{array}$ & Ice- -950 tons & Charter & Oct. 27 \\
\hline \multirow[t]{5}{*}{1860} & February & Nakhimov & Coal-150 tons & $\mathrm{RAC}$ & March 1 \\
\hline & April & Kodiak & Ice-355 tons & RAC & Wrecked \\
\hline & May & Tsaritsa & Ice & $\mathrm{RAC}$ & May 22 \\
\hline & July & Tsaritsa & Ice & RAC & Aug. 11 \\
\hline & October & Tsaritsa & $\begin{array}{l}\text { Ice-3 trips, } \\
2,715 \text { tons }\end{array}$ & $\mathrm{RAC}$ & Oct. 20 \\
\hline \multirow[t]{8}{*}{1861} & January & Nakhimov & Ice-210 tons, furs & RAC & Jan. 20 \\
\hline & April & Nakhimov & Ice-255 tons & $\mathrm{RAC}$ & May 2 \\
\hline & April & Tsaritsa & Ice-930 tons & $\mathrm{RAC}$ & Disabled \\
\hline & April & $N v u E d$ & Ice-270 tons & Charter & May? \\
\hline & July & Elise & Ice-270 tons & Charter & July 25 \\
\hline & July & Franklin Haven & Ice $-1,105$ tons & Charter & Aug. 10 \\
\hline & July & Tsaritsa & Ballast, for repair & RAC & Aug. 11 \\
\hline & December & Kamchatka & Ice-280 tons & RAC & Jan. 13 \\
\hline \multirow[t]{5}{*}{1862} & June & Camden (Kodiak) ${ }^{44}$ & Ice-525 tons & Charter & June 27 \\
\hline & June & Kamchatka & Ice-600 tons & RAC & July 5 \\
\hline & June & Dollart & Ice-310 tons & Charter & July 7 \\
\hline & August & Kamchatka & Ice-600 tons & $\mathrm{RAC}$ & Sept. 10 \\
\hline & September & Windward & Ice- -820 tons & Charter & Sept. 12 \\
\hline
\end{tabular}

${ }^{44}$ Henceforth all vessels with ice came from Kodiak (Wood Island). 


\begin{tabular}{|c|c|c|c|c|c|}
\hline \multicolumn{2}{|c|}{$\begin{array}{c}\text { October } \\
\text { Departure Date }\end{array}$} & $\begin{array}{l}\text { Regulator } \\
\text { Ship }\end{array}$ & $\begin{array}{l}\text { Ice-965 tons } \\
\text { Cargo }\end{array}$ & $\begin{array}{l}\text { Charter } \\
\text { Owner }\end{array}$ & $\begin{array}{l}\text { Oct. } 13 \\
\text { Arrival } \\
\text { Date }\end{array}$ \\
\hline \multirow[t]{9}{*}{1863} & February & Nakhimov & $\begin{array}{l}\text { Ice-290 tons, } \\
\text { sealskins }\end{array}$ & RAC & Feb. 16 \\
\hline & May & Shelikhov & Ice-200 tons & RAC & June 2 \\
\hline & June & Nakhimov & Ice-290 tons & RAC & June 18 \\
\hline & July & Hamburg & Ice-? & Charter & July 26 \\
\hline & July & Dollart & Ice -310 tons & Charter & Aug. 3 \\
\hline & July & Constance & Ice-? & Charter & Aug. 10 \\
\hline & August & Nakhimov & Ice-290 tons & RAC & Aug. 30 \\
\hline & September & Helios & Ice- 775 tons & Charter & Sept. 18 \\
\hline & September & Camden & Ice- 525 tons & Charter & Oct. 5 \\
\hline \multirow[t]{6}{*}{1864} & May & Tsesarevich & Ice -530 tons & RAC & June 5 \\
\hline & June & Nakhimov & Ice-290 tons & RAC & June 13 \\
\hline & June & Caroline Reed & Ice-? & Charter & July 9 \\
\hline & August & Tsesarevich & Ice -530 tons & RAC & Aug. 17 \\
\hline & August & Helios & Ice-775 tons & Charter & Aug. 30 \\
\hline & August & Sophie Helene & Ice-330 tons & Charter & Sept. 10 \\
\hline \multirow[t]{6}{*}{1865} & May & Tsesarevich & Ice -530 tons & RAC & May 27 \\
\hline & July & Tsesarevich & Ice-530 tons & RAC & July 31 \\
\hline & August & Helios & Ice-695 tons & Charter & Aug. 13 \\
\hline & August & Lotta Maria & Ice $-1,140$ tons & Charter & Aug. 30 \\
\hline & August & Susannee & Ice -420 tons & Charter & Sept. 6 \\
\hline & October & Tsesarevich & Ice -530 tons & RAC & Oct. 22 \\
\hline \multirow[t]{4}{*}{1866} & July & Imperial & Ice $-1,730$ tons & Charter & July 13 \\
\hline & August & Kamchatka & Ice- 610 tons & RAC & Aug. 26 \\
\hline & August & Mary Glover & Ice-735 tons & Charter & Sept. 9 \\
\hline & September & Kentucky & Ice-255 tons & Charter & Nov. 11 \\
\hline \multirow[t]{4}{*}{1867} & April & Tsesarevich & Ice-530 tons & RAC & May 4 \\
\hline & June & Helen Angier & Ice- 655 tons & Charter & July 3 \\
\hline & August & Gem of the Ocean & Ice-630 tons & Charter & Aug. 11 \\
\hline & August & Helen Angier & Ice-655 tons & Charter & Sept. 1 \\
\hline
\end{tabular}


APPENDIX II

SUMMARY OF ALASKAN ICE SHIPPED TO CALIFORNIA ${ }^{45}$

$\begin{array}{ccccc}\text { Year } & \text { Shipments } & \begin{array}{c}\text { Tons } \\ \text { Shipped Est. }\end{array} & \begin{array}{c}\text { Tons } \\ \text { Arriving }\end{array} & \begin{array}{c}\text { Gross Receipts in } \\ \text { Thousand Dollars }\end{array} \\ 1852 & 1 & 250 & 200 & 9 \\ 1853 & 4 & 1130 & 850 & 41 \\ 1854 & 6 & 2870 & 2300 & 61 \\ 1855 & 6 & 3385 & 2700 & 52 \\ 1856 & 1 & 710 & 570 & 6 \\ 1857 & 8 & 4555 & 3650 & 21 \\ 1858 & 6 & 3825 & 3390 & 16 \\ 1859 & 9 & 3510 & 2785 & 21 \\ 1860 & 6 & 3075 & 2665 & 24 \\ 1861 & 6 & 3075 & 2665 & 29 \\ 1862 & 6 & 4275 & 3645 & 32 \\ 1863 & 9 & 3570+47 & 2850 & 20 \\ 1864 & 6 & 4785+48 & 3825 & 35 \\ 1865 & 6 & 3835 & 3070 & 25 \\ 1866 & 4 & 3160 & 2525 & 19 \\ 1867 & 4 & 2650 & 2000 & 13\end{array}$

${ }^{45}$ Compiled from Appendix I and Records of the Russian America Company (RG 261).

${ }^{46}$ Indicates change in contract.

${ }^{47}$ Two shipments tonnage unrecorded.

${ }^{48}$ One shipment tonnage unrecorded. 